\title{
Massification of youth religious studies to prevent juvenile delinquency in Bandung
}

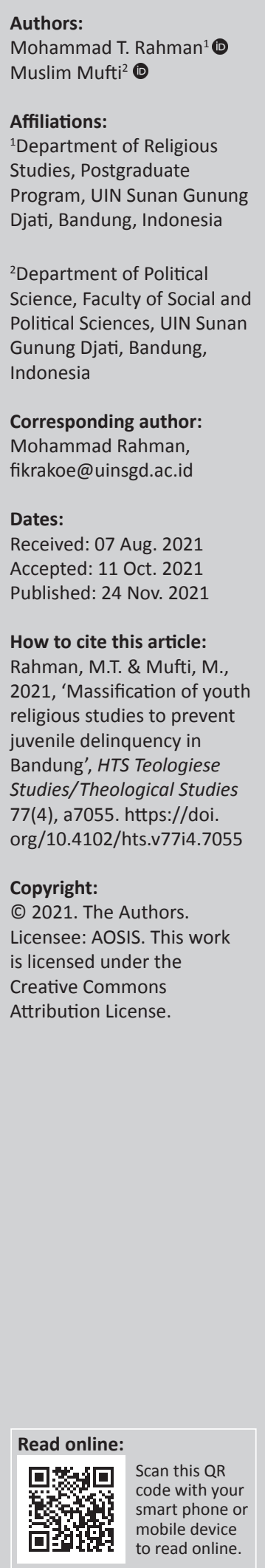

This article suggests that social media and public spaces in contemporary Indonesia play an essential role as a context for Islamic ideologisation by developing social mobilisation methods and transforming its ideology and culture. This socio-phenomenological study highlights the historical and social processes that underlie pious youth's rise in an Indonesia's contemporary urban space, for example, Bandung. The Hijrah [Migrating] Youth Community is an Islamic movement based on mosques and social media such as Twitter, Facebook and YouTube to migrate Hijrah to a better life. This study draws on the forms of articulation culture that emerged from the ideals of the revival and reinvention of Islam in the materiality of secular popular culture. The religious activities of Hijrah youth may reduce the disorders of young people, however since the young are rebellious, extreme religious activities may also arise from the community. Thus, different parties, especially parents, the Bandung City government and other social institutions must supervise the development of the youths' life based on religious parties.

Contribution: This study describes the operation of a youth religious movement, which tries to overcome the problem they usually face, namely juvenile delinquency. This study can develop research patterns that can analyse social phenomena and and apply them to policy consideration.

Keywords: Indonesian Islam; middle-class Muslims; social media; mosque youth; Islamisation.

\section{Introduction}

Technological advances have both positive and negative effects on culture (Alassaf et al. 2020:1367). The positive impacts of the increasing advancement of technology make communication amongst individuals easy and effortless, facilitating state administration, educational facilities, religious dissemination, business development, economic transactions and many other activities now being carried out via the Internet (Iosif 2013:138). The Internet however can provide both constructive and destructive knowledge materials related to necessary and unnecessary lifestyle (Christensen \& Rommes 2019:82).

The negative impact comprise the diminishing traditional cultural values and inappropriate socialising behaviour: drug use, alcohol abuse, illicit racing and adultery (Hoeben et al. 2016:109, 2020:2; Mpondo et al. 2018:43). The rapid flow of globalisation is also inseparable from technological growth. Some analysts claim that the rapid growth of information technology is one of the leading causes of globalisation that happened earlier than anyone thought (Awan 2016:2; Witt 2019:1053). The Internet, electronic commerce, electronic data exchange, virtual services, telemedicine and others have broken down the physical borders between countries (Asadzadeh et al. 2020:100475; Horgan et al. 2020:1), and has led to an influx of information and opportunities. On the other hand, the negative effect of globalisation is a deterioration in people's mindsets (Thurbon 2020:320).

However, it is essential to be cautious while adjusting the ideals of life with all this independence (Ojala, Ladru \& Gustafson 2020:1). The cultural mechanism is feared to be too far away and it is the next generation of teenagers who are affected and suffer the most. Adolescents should always seek advice, clarification and guidance and have access to appropriate information to cope with an unexpected disaster (Guerra, Farkas \& Moncada 2018:310; Khang, Lee \& Kim 2020:454). Teenagers' critical conflict is identity versus identity uncertainty (Dungey \& Ansell 2020:1; Jaspal, Silva Lopes \& Breakwell 2020:2). Therefore, the psychosocial task of adolescents is to establish individuality (Icenogle et al. 2019:69; Mironova 2019:135). To form an identity, teenagers must identify their unique position in society and incorporate their personality's different facets into a 
meaningful whole (Hughes \& Evans 2018:2155; Aschwanden et al. 2020:2281). They have to deal with selecting relevant jobs, colleges, religious system and political party (Ferguson et al. 2019:235; Hufer et al. 2020:762).

Bandung city is one of Indonesia's metropolitan cities where people's lives are very modern and practical, creating an apathetic character in the community. One of the negative impacts is the reduced awareness and interest of young people or adolescents in visiting mosques. In the era of modernisation, the mosque as a worship place for Muslims is less attractive, especially for young people or teenagers. This condition is in stark contrast to the village or rural area where the mosques are always packed and crowded with teenagers who are involved in religious activities. The awareness and concern of teenagers in big cities regarding the prosperity of mosques is very minimal and they pay little attention to mosques, thus making them an unfamiliar place for them. Now young people seldom visit a mosque. Religious activities, such as studying Islam, become the social behaviours of adolescents (Mufti \& Rahman 2019:205; Verkuyten 2018:21). Faith gives meaning to individual and group life; it also provides hope for survival after death (Sohail 2020:928)

On the other hand, adolescents' deviant behaviour often causes harm to both adolescents and those around them (Bryson et al. 2020:3; Copeland et al. 2019:1507). The Hijrah Youth community based in Bandung, Indonesia (hereinafter, the Hijrah) proactively worked towards minimising adolescent deviation by building their socio-religious behaviour based on education and understanding religious values, including suitable activities. However, before delving into this development, let us explore the Hijrah concept in Islamic history.

The idea of Hijrah is far from new because it had its roots in the life of Muhammad when he commanded his faithful followers, who were oppressed at Mecca, to flee for refuge in Abyssinia and then migrate to Madinah. Muslims' migration to Madinah is a well-known Hijrah, and usually, writers and fatwas refer to this critical event (Masud 1990:31-32). This significance was formally affirmed when the Hijrah was chosen to mark the beginning of the Islamic calendar (Masud 1986:59). Hijrah means 'migration'. Conceptually, it has four meanings: (1) the departure of Muhammad from Mecca, (2) the Muslim era, (3) the act of a Muslim leaving a country under infidel rule (Patrick 2013:174) and (4) fleeing from sin (Al-Faruqi 1983:3). Besides some spiritual interpretations, the last meaning seems to be based on the hadith la hijrata ba'd al-fath (there is no Hijrah after the conquest [of Mecca]). Nonetheless, there are hadith texts according to which Hijrah continues to be an obligation (Masud 1990:35-36).

Hijrah implied the idea of an Islamic authenticity. This idea dominated when Muslims were struggling to overcome Western culture and power constraints (Çınar 2018:176; Mandaville \& Hamid 2018:2; Rahman 2010:13). Such views continue to this day. It appears that the Hijrah Youth were trying to rediscover the authenticity of Islam based on the texts of the Qur'an and Hadith. Hijrah became the mainstream Islamic renewal thinking in the early 20th century (Arkoun \& Lee 2019:12; Kamali 2018:69; Lee 2018:5).

The question is, to what extent could the youth overcome juvenile delinquency by delving into Islamic studies? This question will be answered with a case study design used to investigate in detail the alternative conceptions of new youth, their framework and religious learning and practice in their lives in Bandung, Indonesia.

\section{Research method and design}

Social phenomenology is the method used in this research. Social phenomenology includes focusing on the problems that present when analysis or actual issues are carried out, describing the situation as examined and accompanied by an excellent rational interpretation and making the objects make sense of their experiences (Paley 2016:16; Vanderlinden et al. 2020:100224; Vincini \& Gallagher 2020:3). In so doing, we collected, analysed and directly contacted the Hijrah Youth Community, at Al-Lathiif Mosque, Jalan Saninten and the Mosque Trans studio in Bandung for data collection relating to the subject of the study (Chadwick 2017:56; Loughlin et al. 2018:920; Swedberg 2018:185). The data were obtained from interviews with the Hijrah Chairperson, the Hijrah Administrators and the Hijrah members. The purpose of this research is to describe the ongoing problem and discover Hijrah's contribution to social development amongst adolescents in Cihapit Village of East Bandung District of Bandung City.

\section{Research findings and discussion Origins of the Hijrah Movement in Bandung}

There was an awareness amongst some youth who cared about the behaviour of teenagers. They gathered and united with a clear vision, mission and goal for developing Youth social behaviour in Bandung city prevent young people from becoming to corrupt and victims of modernisation. By starting the campaign 'Come to the Mosque', the Hijrah (the community called itself Shift), community was formed by involving the Administrator of Mosque AL-Lathiif in all their activities. Starting from a study at the Al-Lathiif Mosque, located at Jalan Saninten No. 2 of the Bandung City of West Java, many youths who used to have delinquency problems finally decided to move. After settling on the path they were taking, they tried to persuade other youths to change. Of course, the sermon must be customised to many things that young people enjoy, such as social media. They campaigned through blogs, Instagram, Facebook and YouTube. The name Shift was chosen as the symbol for the movement. The Shift is a movement for youth Hijrah who want to leave things that God forbids. The youth Hijrah is a forum for young people who want to migrate from evil and get closer to God. 
The Hijrah and the Al-Lathiif Mosque Administrator made it their mission to preach to young people in Bandung city in an attractive, fun and friendly way and lead them back to the right path and explore Islam. In this present time of information age, Muslim youth and girls are far from the mosque; they prefer to be involved in unproductive activities that are waste of time and vain leading them to sin. It is because young people are far from the mosque, resulting that the propagation does not reach the youth. This main objective of this movement is to persuade and encourage young people to go to the mosques and attend Islamic religious studies. This movement has also attracted enough attention on social media (Interview with IN, respondent 3, 32, male, public relations).

Advances in information technology can also be used to preach, as has been done by the Hijrah. By utilising social media such as Instagram, Facebook, Line, Twitter and YouTube, the youth community were able to effectively migrate the preaching and target the teenagers who are very close to social media. Today, Instagram helps develop the world of propagation in Indonesia to increase Indonesian celebrities' migration, inspiring some people to emigrate. The philosophy of Hijrah is based on one of the Hijrah founders explanation of IN. According to IN, a member of the Hijrah is a devout youth, namely living a life according to Islamic guidance. However, they are still cool in their social and community life and can even mingle with friends even by paying attention to Islamic manners. Furthermore, they can also influence their friends in the community to move to the proper ways of Islam. For example, the Hijrah community has a Brand Ambassador, namely PP, a national skateboarder who had become an idol in Bandung City. PP is a skateboarder, an obedient but funny young man. He works and mingles in his skateboarding community, but is a pious youth who listens to Al-Qur'an recitation whilst practicing skateboarding, performs prayers on time, does routine recitation of the Al-Qur'an and has memorised the Al-Qur'an, thus becoming a role model for the Islamic youth. Similarly, there is ER, a national footballer; DS, an ex-vocalist of an underground band; KA, who is chairman of the motorcycle gang of Brigez. And there is also FK, a skateboarder and national surfer, at the same time one of the founding community Hijrah youth and other such inspiring figures. We can see that the Hijrah movement have significantly used popular figures to inspire other youth. The massification therefore was based on the 'charisma' of influencing people (Weber 1993:13).

The Hijrah is better known as Shift, another word for 'Hijrah which means change, displacement etc. It was founded in 2015 by youths from various communities in Bandung City. These include skateboarding, parkour, indie music, BMX bikers, and motorcycle gang members who pledged to deepen Islam (Interview with ID, 01 April 2019). Hijrah youths were born out of concern for adolescents', especially in Bandung, far from the mosque, who prefer to be involved in such unproductive activities that are a waste of time and lead them to sin.. The existing concept of 'propagation communication' has been unable to stimulate young people to come to religious science assemblies, therefore a new idea was needed that could embrace young people (IN, respondent 3, 32, male, public relations).

The Hijrah is a youth-led Islamic organisation based in Bandung, Indonesia. The youth take part in religious and social activities in the mosque. The group aims to give 'crunchy' propagation through an engaging, funny, friendly and contemporary approach. For about 6 years, the Hijrah community preached, inviting Bandung youth to go back to the right path. The Hijrah has become a phenomenon in teenage life; it has even become a lifestyle in Bandung City. It can be seen from the Instagram account of the Hijrah, which has 660000 followers, that a massive number for a community has been established over a period of 6 years.

The Hijrah has also succeeded in attracting teenagers in other cities. As the Hijrah became increasingly famous, various appreciations and acknowledgments began to arrive, one of which came from the Regional Secretary of West Java, who took time to attend one of the studies held by the Hijrah. The most recent achievement of the Hijrah is getting financial assistance from one of the zakat agencies to carry out the activity of Go-Nusantara Shift. The purpose of this activity was to make visits and studies to other cities with the aim to preaching to teenagers outside Bandung city, hoping that this 'virus' of preaching could spread to other cities. The number of Hijrah followers has not been ascertained yet because so many participants come to each study, registration is held to become a Shift volunteer. So, the participants feel involved in every activity regulated by the Hijrah youth.

\section{Management of the Hijrah}

A general chairman of the Hijrah Youth Group, called JL (respondent 5, 32, male, public relations), is the movement's guiding force. It also has a general secretary, treasurer and supervisor. Other administrators are in coaching, education and YD (Respondent 2, 29, male, teacher) training to schedule the Hijrah activities, make education and coaching curricula, make teaching schedules, debriefing concept study materials and Go-Shift (mosque safaris). The productivity sector of IMK (Respondent 1, 34, male, entrepreneur), with the function of making merchandise for sale, is usually in shirts, sweaters, jackets, hats and accessories.

The information and communication sector coordinates information within internal institutions and social media such as websites and other online media. The research and development field of ADF (Respondent 6, 19, female, teacher) with the role of examining the development and life of adolescents, to be used as study material facilities and infrastructure sector to take care of the needs in every activity of the Hijrah. Activities were carried out at Al-Lathiif Mosque, Trans Studio Bandung Mosque, mosque safaris and activities carried out outdoors. 


\section{Hijrah's philosophy}

Hijrah's vision is to increase the interest of young people to come to the mosque. Its mission is: (1) changing the lifestyle of young people by changing the mindset that a young man is one who has memorised the Qur'an, who often participates in $\mathrm{ta}^{\prime} \mathrm{lim}$ (religious learning), prays at dawn at the mosque, (2) presenting an inspirational figure who can be used as a role model, (3) changing young people's perspective that Islam is a fun religion that can be used as a guide for life, (4) contribute directly to building adolescent behaviour, (5) creating a youth figure who follows Islamic guidance, namely youth who are close to the Qur'an, pray on time, are enthusiastic in seeking religious knowledge and then become a better generation in following the tenets of the Prophet Muhammad SAW (Sallallah Alaih Wasallam [peace be upon him]). Shift, established in early 2015, means moving; in the language of religion it means moving from bad to good or from good to better. Because Shift is only heard nowadays, therefore the next generations know the Hijrah youth (Interview with ID, 01 April 2019).

There are two symbols of the Hijrah that are often encountered which have their respective philosophies. The first logo has a black background and writing in gold. The ethos is black, depicting the dark past of the Hijrah members and the inscription Shift is in gold, defining a future that is expected to be full of glory. The second logo has a black background and has the word Shift in white; black depicts their lousy past and Shift in white is an indicator of their religious philosophy. The point is to move from an unfavourable past to holiness or to emigrate.

\section{Hijrah's programmes}

To contribute significantly to building adolescent social behaviour in Bandung city, the Hijrah offers several activities, including religious activities, sports or just a gathering. These activities are carried out to fill teenagers' time with things that are useful and more productive. The purpose of holding these activities is to bring the young generation of Bandung City closer to the mosque to avoid actions that lead to sin. Following the Hijrah's motto of 'plenty plays, plenty benefits, rewards and a little sin'. Hijrah activity programmes include systematic studies, learning the Qur'an, practicing during the fasting month, mosque safari, charity activities, Arabic learning, joint tattoo removal and education (tarbiyah).

The Hijrah hold regular studies in two different places. The theme of the study is usually more severely related to the afterlife. Monday night, the study is carried out at the AlLathiif Mosque. Teacher Tengku Hanan Attaki, commonly called Teacher Hanan, is the founder of Shift or the Hijrah. His style is relaxed and the material presented is light not heavy. The aim is that young people who are just learning to deepen the Islamic religion can understand. Ladies day is specifically for female congregations. The material presented is usually light, such as love life, life as students or everyday life. The Satnight is a colloquial term for Saturday night study sessions. The research was carried out at the Al-Lathiif Mosque on Saturday night. Teacher EE (Respondent 7, 39, male, preacher) packed the study with information that is relevant to today's youth. Qiyamullail activities fill the evening activities with worship, referring to worshiping at night by performing sunnah prayers. This activity usually starts at two in the morning and ends with the morning prayer.

Routine studies at the Hijrah are held every Monday, Wednesday and Saturday. Monday's study requires a wiser and more mature understanding of digesting the material. On Wednesdays, studies usually bring themes about how to respond to our lives in the world. Teacher Hanan delivered this Wednesday study. On Saturdays, the analysis was typically provided by Teacher EE, with a funny delivery and a language that was easy to understand. The women's study happens every Saturday at 09:00 in Al-Lathiif Mosque. The Hijrah is taking part in a social media Islam study. One assembly learned about the study via Instagram. A group's member said: 'My friends invited me because many people participated in the study' (Interview with AS, 16 August 2019).

The effort of the Hijrah to attract many worshippers with routine study activities can be said to be successful:

'It means that our propagation is successful when someone who says it is not good keeps trying to go to the mosque to be good because that is our goal.' (Respondent 12, 25, male, organiser)

From the given statement, the Hijrah has succeeded in making routine study activities their instrument to achieve their goals, namely increasing awareness and interest of youth to come to the mosque.

The tahsin method is a method for perfecting the pronunciation of the verses of the Qur'an. This tahsin activity is usually held on Tuesday evenings at the Al-Lathiif Mosque. Participants are also helped in memorising the Qur'an, and a rote test is carried out at in the next meeting. In addition to learning tahsin, there are also maqamat learning activities (reciting the Qur'an) with Teacher MH (Respondent 8, 46, male, teacher). This activity aims to make teenagers in Bandung able to read the Qur'an correctly.

The Hijrah familiarises members and congregation with sunna, one of which is sunna fasting. Sahur is usually carried out in the middle of other activities. The Hijrah still often get invitations from friends to drink alcohol, consume drugs and commit adultery and they refuse them. The Hijrah routinely performs sunna fasting together. Qur'an recitation is usually held whilst waiting for the Maghrib call to prayer.

There is also a more comprehensive and profound learning programme, that is, the tarbiyah (education). This tarbiyah programme aims to give birth to young generations to have a concept or mindset for following Islamic law. Here Islam is not just a ritual of worship, but Islam is a life system; this is 
what the Hijrah is trying to instil in adolescents in Bandung. Here participants are required to have attended a systematic study for at least 3 months. Previously, participants were required to register as volunteers, and their attendance at the review will be recorded as absent. The tarbiyah programme is held at the Al-Lathiif Mosque for one whole week, during which the participants are not allowed to go home unless it is very urgent. Its activities include compulsory prayer and congregational sunna, reading and deepening the Qur'an, receiving material from the Teachers, qiyamullail and performing other religious practices under the guidance of Teacher Hanan and Teacher NR (Respondent 9, 43, male, teacher). Tarbiyah is usually held during the school or college holidays to not interfere with the school and lecture schedules of the participants and the committee (Interview with ID, 01 April 2019).

\section{Social behaviour of the Hijrah}

As a country with a majority Muslim population, finding religious study activities is straightforward. It starts from a small scale such as $t a^{\prime} l i m$, which is usually held in villages and regions to a large scale such as tabligh akbar, seminars on religion, to national level studies with lecturers who already have big names. But not all of these study activities were able to attract young people and this is because the concept of propagation communication that has been available so far cannot touch young people. As stated by IN, one of the founders of the Hijrah:

'Actually there are also many religious studies out there, but what I see is not sufficient and can not touch young people, the existing studies tend to be stiff and boring want to make a study that is different from the others in terms of concepts and materials.' (Respondent 3, 32, male, public relations)

The mission of the Hijrah is to get teenagers to come to the mosque as a form of direct contribution in an effort to build adolescent social behaviour in Bandung city, given the shallow interest of young people to come to mosques amidst the current modernisation. One of the most popular activities of the Youth Hijrah movement is packaged religious studies. At the beginning of its appearance, many thought that the Hijrah was a community that only held study activities; the study however, was only one of the many Hijrah programmes. As stated by the Human Relations officer of Hijrah:

'Maybe what people know that we are EO (Event Organizer) ta'lim is wrong, EO ta'lim or study is just one of our products. It also needs to be clarified that the Youth Hijrah Movement is not EO ta'lim; one of our activities is the $t a^{\prime}$ lim itself. The first activity we sounded on social media was a study because the first step we had to do was get young people to come to the mosque. By providing flexible material and also bringing in figures that are popular with young people, maybe it can make them come to the mosque because their idols are in the Hijrah.' (Interview with ID, Human Relations officer, 01 April 2019)

The Hijrah uses study activities as a tool or instrument to foster youths' interest in coming to the mosque with the hope that the congregation that is present will feel part of the Hijrah; of course, the final goal is to build social behaviour teenagers. The Hijrah creates variations in studies dubbed GO-Shift (mosque safari) and abrupt Shift (studies outside the mosque), the latest is the West Java GO-Shift Tour programme, namely studies in different West Java cities. In every activity carried out by the Hijrah and building adolescent social behaviour and inviting them to return to the right path, all members and administrators are always involved in the community, especially youth, to come to the mosque. As explained by the PR:

'Yes, we hope that mosques are no longer a foreign place to them, mosques can be a hangout place for young people, especially in Bandung, hopefully, they can spread to other cities.' (Interview with ID, public relation officers of the Hijrah, 01 April 2019)

From the given statement, the Hijrah's public relation point of view is explained that a different way is needed to invite young people to come to the mosque. One of the ways considered the most effective is utilising social media technology that is very close to the daily lives of teenagers today. Furthermore, the public relations officer of the Hijrah explained:

'Second, because our target of young congregations is very diverse, from skaters to musicians, we must adapt the posters to their hobbies. From the concept, the title, to the letterforms, we invite young people to the mosque. Concept and branding We have thought about these that the people are young.' (Interview with ID, public relations officer, 01 April 2019)

Brother ID's statement was also corroborated by the idea of another member, namely BZ, who added:

'We also have the figure of a teacher, maybe if the teacher pays
attention which is different from the cleric in other places. The
Teachers are young people, why do you wear a t-shirt? Why are
you using a beanie? How cool? The teacher does not need to
wear a robe because we are looking for the essence of his study's
content. It is the little things like this that we have the brand.
Then the concept, because when we have an idea, it will be vital.
If we have a ta'lim product but just join in, I am sure it will only
last for a while, so it just passes away.' (Respondent 10, 24, male,
organiser)

The Hijrah uses the following methods to invite teenagers to the mosque: inviting teens with social media, using invitation posters, the figure of cowboy Teacher and trending concepts.

The most effective way to approach young people is to use social media. Hijrah already has an application that can be used for live streaming studies; the application can be downloaded on Google Play Store. Still, in social media, posters are considered a powerful way to promote a product; in this case, the product being offered is a study targeting the youth market. A sign that is made cannot be just an ordinary poster; of course, it must be a poster following the hobbies of young people. Characters can invite and inspire the hearts of young people. Like other places, the Hijrah supplied its teachers with information that was casual and easily 
understood by young people without compromising the essence of the lecture's topic.

The concept is considered to be very prominent in the work of the Hijrah. They have a different idea of propagation from others. The opinions offered are very close to young people, including socialisation concepts, posters, activity programme concepts and material themes. Everything has been conceptualised to close to the life of the youth as possible. It can be concluded that the Hijrah uses a different way of inviting teenagers to come to the mosque and attend the study. Posters are made to suit young people's hobbies to ask teenagers to participate in the study.

\section{Social action}

To understand social action in the Hijrah, the researchers analysed Weber's social action theory. For Weber, social action is the most fundamental concept in the field of sociology. Social action is all human behaviour that has a subjective meaning (Weber 1978:33). The element that Weber emphasised is the personal meaning of a perpetrator (Weber 2002:45). Weber's social action should not be limited to positive steps that can be noticed immediately (Vuori, Aher \& Kylänen 2020:119). Activities also include negative actions such as failure to do something or passively accept a situation. Social behaviour is a character or personality trait of a person's actions that can be observed when someone interacts or makes effort with other people or their environment.

The Hijrah uses study activities and social media as supporting instruments in achieving the goal. This behaviour has been considered according to the environmental conditions that exist in Cihapit Village. All members of the Hijrah have the same plan carried within them, namely to return to the right path or to migrate. The following is the statement of the PR:

'I think the influence after the Shift, especially for young people in Bandung City, they want to go to mosques, mosques are no longer a foreign place to them, mosques become hangout places for young people, young people in Bandung become obedient. But still cool. It can be seen from the study participants that they come from various backgrounds and backgrounds, some of them only wearing t-shirts with tattoos; maybe for the ordinary people, they are surprised that people with tattoos are diligent in going to the mosque? It means that our propagation is successful when someone who says it is not good keeps trying to go to the mosque to be fair because that is our goal.' (Interview with ID, 01 April 2019)

The Hijrah plays an important role not only in terms of building adolescent social behaviour but also in inviting the public to come to the mosque and participate in religious activities. These considerations eventually resulted in a method or approach to invite people to go to the mosque. This step is taken to build social behaviour, especially in adolescents, such as the following PR statement:

'Our latest activity is charity renovating the hafiz pesantren (religious school for memorizing the Qur'an) in Taraju of
Tasikmalaya Regency. If there are floods, we like to sound it through social media for donations flood victims, raising funds for the Palestinians because it happened sometime yesterday we were the arrival of one of Palestine's priests. There we raise funds for the activities of humanity.' (Interview with ID, 01 April 2019)

The activities carried out by the Hijrah were effectual, in the sense that they will affect the actions or responses of people in their deeds: in this case, the actions taken by members of the Hijrah to migrate and build adolescent social behaviour. Based on the findings of existing data, the Hijrah carried out the study activities. They feel calm and gain a lot of new knowledge. This calmness makes the person feel happy or excited when participating in a study activity. As one of the informants opined:

'At first I knew it from Instagram, friends invited me because many people participated in the study here, so I was curious. Thanks are to God, I got a lot of knowledge about Islam, made many new friends whose thoughts about the afterlife are not only about pursuing the world, and have become calmer.' (Interview with AS, 16 August 2019)

There was also valuable rational action as this kind of activity is related to a commitment made with full awareness. It cannot be separated from religious values, law and various other forms of discounts. This action is determined by a belief that is aware of the distinctive importance of ethical, aesthetic, religious or other forms of behaviour, regardless of the prospects for success (Weber 1978:36). As was done by all members and congregations of the Hijrah, they are aware that it is imperative to build social behaviour for teenagers considered far from mosques and religion. They are also consciously committed to migrating together. As stated by one of the Hijrah public relations officers:

'Firstly, it is from the ta'lim which is only two lines, then from there the idea of making the Shift/Hijrah movement is with the teacher too, because maybe we feel we need something like this, maybe. In our perspective, there are many people out there who are unhappy with conditions that are outside their exterior, we believe there are many communities in Bandung, right? Skateboards, music, BMX bikes, a parking community, a religious community, and all that. So shift means movement, so it means the tendency to combine several of these communities.' (Interview with DN, 02 April 2019)

\section{Gaining the idea of Hijrah}

It appears that in Bandung, the presence of the Hijrah group has provided a positive offer for young people who are already in the realm of technological advancement (Alassaf et al. 2020:1367; Mihelj, Leguina \& Downey 2019:1465), namely by conducting massive religious studies using various methods, including those based on the latest information technology (Duan, Edwards \& Dwivedi 2019:63). Thus, the negative impact of technological advances on young people can be mitigated by religious activities (Hoeben et al. 2016:122, 2020:37; Keeler et al. 2019:38; Mpondo et al. 2018:49). However, studies show that placing too much emphasis on religious education can reduce tolerance and 
promote extremism in young people (Ghannouchi 2020:44; Smith, Nixon \& Pearce 2018:361). It is a problem that those concerned with the development of youth activities could immediately anticipate because the idea of Hijrah itself is the idea of authentication, bringing about the concept of selection, selected and unselected. It includes the idea ingroup and out-group. Therefore, it is the idea of separation or seclusion from others. And it could be a dangerous idea if it brings in an extreme way. For instance, Islamic history could tell us the following:

Since the 12th century, a new dimension of the question of Hijrah came to light. As mentioned before, many Muslim areas, especially in the Islamic west, were captured by nonMuslim (Masud 1986:60). The problem was whether one was allowed to give up fighting and to remain living under nonMuslim rule or whether one was obliged to continue the armed resistance or to emigrate to an area governed by a Muslim ruler (Shadid \& Van Koningsveld 1996:91). The answers based on religious arguments - usually called a fatwa - were divided into two opinions: to migrate and not to migrate from those Christian-occupied areas (Masud 1986:60).

In the very beginning, that is, in 1492, Al-Wansharisi had urged the Andalusian Muslims under Christian rule to emigrate to the 'Territory of Islam' (Shadid \& Van Koningsveld 1996:91). The question was also raised when the Muslims suddenly found themselves outside the boundaries of dar al-Islam in the Ottoman empire, with which they linked their fate and outside which their life was unthinkable (Al-Arnaut 1994:246). This problem was discussed all over the Muslim world during the late 19th and early 20th centuries (Shadid \& Van Koningsveld 1996:91) and the Hijrah movement was straight ahead.

Muslim emigration was speeded up from the Crimea after the wars of 1806-1812, 1829 and 1854-1856, from Serbia from 1830 to 1878, from Bulgaria in 1877-1878 and from Bosnia throughout 1878-1918 (Karpat 1985:66, 2002:132). Regarding Bosnia, we have a Hijrah that deserves close attention, namely that which took place during Austro-Hungarian rule (1878-1918) and evicted about 150000 Muslims from Bosnia (Al-Arnaut 1994:243). In Bosnia itself, at the end of 19th century, there was a fatwa convinced by Azapagic that the 'Territory of War' (dar al-harb) would become the Territory of Islam (dar al-Islam) if Islamic religious rites and observances like Friday prayers and feast prayers would be practiced there (Shadid \& Van Koningsveld 1996:90). Here a doctrine of Hijrah had a challenge. This challenge also happened in Africa when there were Hijrah led by Syaikh Uthman ibn Fudi in Nigeria (1804) (Masud 1990:61), Hijrah from Tlemcen (Algeria) in 1911 (Ageron 1967:1080) and Hijrah from India by the Khilafat Movement (1920) (Hasan 1981:72). Another dimension of Hijrah also emerged when for higher education, training and employment, Muslims travelled to non-Muslim lands and stayed there for more extended periods. In some cases, they migrated to settle.
However, these countries that have made pacts and treaties with Muslims are no longer dar al-kufr (territory of unbelievers) (Masud 1990:42-43). The doctrine of Hijrah consequently faces new challenges.

One might expect an activity like that of Hijrah in Bandung as a frame of reference to prove restrictions on subsequent interpretations. However, the doctrine of Hijrah has been quite adaptable to varying contexts. Sometimes, the same texts have been interpreted to justify widely different fatwas from a concept of Hijrah. This flexibility is because of the acceptability of these interpretations, not the doctrine itself. There is something we may call a 'semantics of expectation' on the part of society (Masud 1990:45). Here, words acquire new meanings according to these expectations. The shifts of meanings of Hijrah, dar al-Islam and dar al-harb in some fatwas and activities are examples of this semantic expectation.

\section{Conclusion}

The context of developing the Hijrah Youth Community focuses on caring for adolescents' problems, especially in Bandung, in developing themselves amidst various advances, including technological advancements. The Hijrah facilitates activities that can build positive social activities amongst teenagers. These activities include: studying Islam regularly, performing rituals together, visiting each other's places of action and social service by giving something good, whether things such as food or aid activities. The religious activities provided by the Hijrah can indeed reduce the evil actions of young people. Because young people are rebellious by nature, there is a probability that extreme movements may emerge from the religious group. Therefore, the youth and the activities must be balanced with supervision from various parties, especially the parents, the Bandung City government and other social institutions. This is a socio-phenomenological study therefore the acquisition is still in the form of an interactive explanation of the social organisation from the parties in the organisation. Studies of functional and conflict sociology can be continued to study this youth group in Bandung or the kind elsewhere, to develop more comprehensive and operative conclusions.

\section{Acknowledgements}

The authors would like to express their gratitude to Pemuda Hijrah activists, Bandung City, for their willingness to participate in this research.

\section{Competing interests}

The authors declare that they have no financial or personal relationships that may have inappropriately influenced them in writing this article.

\section{Authors' contributions}

Both authors contributed to the writing of the article and approved the final manuscript for publication. 


\section{Ethical considerations}

This article followed all ethical standards for research without direct contact with human or animal subjects.

\section{Funding information}

This research received no specific grant from any funding agency in the public, commercial or not-for-profit sectors.

\section{Data availability}

Data sharing is not applicable to this article as no new data were created or analysed in this study.

\section{Disclaimer}

The views and opinions expressed in this article are those of the authors and do not necessarily reflect the official policy or position of any affiliated agency of the authors.

\section{References}

Ageron, C.-R., 1967, L'émigration des musulmans algériens et l'exode de Tlemcen (1830-1911), Annales: Histoire, Sciences Sociales, vol. 22, pp. 1047-1066, Cambridge University Press, Cambridge.

Al-Arnaut, M.M., 1994, "Islam and Muslims in Bosnia 1878-1918: Two "Hijras" and two "Fatwās"', Journal of Islamic Studies 5(2), 242-253. https://doi.org/10.1093/ jis/5.2.242

Alassaf, D., Dabić, M., Shifrer, D. \& Daim, T., 2020, 'The impact of open-border organization culture and employees' knowledge, attitudes, and rewards with regards to open innovation: An empirical study', Journal of Knowledge Management 24(9), 2273-2297. https://doi.org/10.1108/JKM-02-2020-0122

Al-Faruqi, I.R., 1983, The Hijra: The necessity of its lqamat or Vergegenwartigung, Muslim Youth Movement of Malaysia, Kuala Lumpur.

Arkoun, M. \& Lee, R.D., 2019, Rethinking Islam: Common questions, uncommon answers, Routledge, London.

Asadzadeh, A., Pakkhoo, S., Saeidabad, M.M., Khezri, H. \& Ferdousi, R., 2020, 'Information technology in emergency management of COVID-19 outbreak', Informatics in Medicine Unlocked 21, 100475. https://doi.org/10.1016/j.imu.2020.100475

Aschwanden, D., Strickhouser, J.E., Sesker, A.A., Lee, J.H., Luchetti, M., Stephan, Y. et al., 2020, 'Psychological and behavioural responses to coronavirus disease 2019: The role of personality', European Journal of Personality 35(1), 51-66. https://doi.org/10.1002/per.2281

Awan, A.G., 2016, 'Wave of anti-globalization and capitalism and its impact on world economy', Global Journal of Management and Social Sciences 2(4), 1-21.

Bryson, S.L., Brady, C.M., Childs, K.K. \& Gryglewicz, K., 2020, 'A longitudinal assessment of the relationship between bullying victimization, symptoms of depression emotional problems, and thoughts of self-harm among middle and high schoo students', International Journal of Bullying Prevention 3, 182-195. https://doi. org/10.1007/s42380-020-00073-4

Chadwick, R., 2017, 'Embodied methodologies: Challenges, reflections and strategies', Qualitative Research 17(1), 54-74. https://doi.org/10.1177/1468794116656035

Christensen, T.H. \& Rommes, E., 2019, 'Don't blame the youth: The social-institutional and material embeddedness of young people's energy-intensive use of information and communication technology', Energy Research \& Social Science 49, 82-90. https://doi.org/10.1016/j.erss.2018.10.014

Çınar, M., 2018, 'Turkey's "Western" or "Muslim" identity and the AKP's civilizational discourse', Turkish Studies 19(2), 176-197. https://doi.org/10.1080/14683849.20 17.1411199

Copeland, M., Siennick, S.E., Feinberg, M.E., Moody, J. \& Ragan, D.T., 2019, 'Social ties cut both ways: Self-harm and adolescent peer networks', Journal of Youth and Adolescence 48(8), 1506-1518. https://doi.org/10.1007/s10964-019-01011-4

Duan, Y., Edwards, J.S. \& Dwivedi, Y.K., 2019, 'Artificial intelligence for decision making in the era of big data - Evolution, challenges and research agenda', International Journal of Information Management 48, 63-71. https://doi.org/10.1016/j. ijinfomgt.2019.01.021

Dungey, C.E. \& Ansell, N., 2020, “'I go to school to survive”: Facing physical, moral and economic uncertainties in rural Lesotho', Children's Geographies 18(6), 614-628. https://doi.org/10.1080/14733285.2020.1822514

Ferguson, H.L., Swann, C., Liddle, S.K. \& Vella, S.A., 2019, 'Investigating youth sports Coaches' perceptions of their role in adolescent mental health', Journal of Applied Sport Psychology 31(2), 235-252. https://doi.org/10.1080/10413200.2018.1466839

Ghannouchi, R., 2020, 'Deradicalization through religious education', in Routledge handbook of deradicalisation and disengagement, pp. 154-160, Routledge, London.
Guerra, C., Farkas, C. \& Moncada, L., 2018, 'Depression, anxiety and PTSD in sexually abused adolescents: Association with self-efficacy, coping and family support', Child Abuse \& Neglect 76, 310-320. https://doi.org/10.1016/j.chiabu.2017.11.013
Choust

Hasan, M., 1981, 'Religion and politics: The Ulama and Khilafat Movement', Economic and Political Weekly 16(20), 903-912.

Hoeben, E.M., Meldrum, R.C., Walker, D. \& Young, J.T.N., 2016, 'The role of peer delinquency and unstructured socializing in explaining delinquency and substance use: A state-of-the-art review', Journal of Criminal Justice 47, 108-122. https:// doi.org/10.1016/j.jcrimjus.2016.08.001

Hoeben, E.M., Osgood, D.W., Siennick, S.E. \& Weerman, F.M., 2020, 'Hanging out with the wrong crowd? The role of unstructured socializing in adolescents' specialization in delinquency and substance use', Journal of Quantitative Criminology 37, 141-177. https://doi.org/10.1007/s10940-019-09447-4

Horgan, D., Hackett, J., Westphalen, C.B., Kalra, D., Richer, E., Romao, M. et al., 2020 'Digitalisation and COVID-19: The perfect storm', Biomedicine Hub 5(3), 1-23. https://doi.org/10.1159/000511232

Hufer, A., Kornadt, A.E., Kandler, C. \& Riemann, R., 2020, 'Genetic and environmental variation in political orientation in adolescence and early adulthood: A nuclear twin family analysis', Journal of Personality and Social Psychology 118(4), 762. https://doi.org/10.1037/pspp0000258

Hughes, D.J. \& Evans, T.R., 2018, 'Putting "emotional intelligences" in their place: Introducing the integrated model of affect-related individual differences', Frontier in Psychology 9, 2155. https://doi.org/10.3389/fpsyg.2018.02155

Icenogle, G., Steinberg, L., Duell, N., Chein, J., Chang, L., Chaudhary, N. et al., 2019 'Adolescents' cognitive capacity reaches adult levels prior to their psychosocial maturity: Evidence for a "maturity gap" in a multinational, cross-sectional sample', Law and Human Behavior 43(1), 69. https://doi.org/10.1037//hb0000315

Iosif, D., 2013, 'On a new approach to problems of communication', Media and information literacy for knowledge societies, pp. 138-148, Interregional Library Cooperation Centre, Moscow.

Jaspal, R., Silva Lopes, B.C.D. \& Breakwell, G.M., 2020, 'British national identity and life satisfaction in ethnic minorities in the United Kingdom', National Identities 1-18. https://doi.org/10.1080/14608944.2020.1822793

Kamali, M.H., 2018, Tajdid, Islah and civilisational renewal in Islam, Internationa Institute of Islamic Thought (IIIT), Herndon, VA.

Karpat, K.H., 1985, Ottoman population, 1830-1914: Demographic and socia characteristic, University of Wisconsin Press, Madison, WI.

Karpat, K.H., 2002, 'The hijra from Russia and the Balkans: The process of selfdefinition in the late Ottoman state', in Studies on Ottoman social and political history, pp. 689-711, Brill, Leiden.

Keeler, B.L., Hamel, P., McPhearson, T., Hamann, M.H., Donahue, M.L., Prado, K.A.M. et al., 2019, 'Social-ecological and technological factors moderate the value of urban nature', Nature Sustainability 2(1), 29-38. https://doi.org/10.1038/s41893-018-0202-1

Khang, M., Lee, D.H. \& Kim, Y., 2020, 'Parental perceptions of surviving sibling grief responses to an adolescent's violent and sudden death by the Sewol ferry disaste in South Korea', OMEGA - Journal of Death and Dying 81(3), 454-474. https://doi. org $/ 10.1177 / 0030222818777340$

Lee, R.D., 2018, Overcoming tradition and modernity: The search for Islamic authenticity, Routledge, London.

Loughlin, M., Mercuri, M., Pârvan, A., Copeland, S.M., Tonelli, M. \& Buetow, S., 2018 'Treating real people: Science and humanity', Journal of Evaluation in Clinical Practice 24(5), 919-929. https://doi.org/10.1111/jep.13024

Mandaville, P. \& Hamid, S., 2018, 'Islam as statecraft: How governments use religion in foreign policy', in Brookings New Geopolitics of the Middle East Report, pp. 1-28, Foreign Policy at Brookings, Brookings.

Masud, M.K., 1986, 'Shehu Usuman Dan Fodio's Restatement of the Doctrine of Hijrah', Islamic Studies 25(1), 59-77.

Masud, M.K., 1990, 'The obligation to migrate: The doctrine of hijra in Islamic law Muhammad Khalid Masud', in Muslim travellers: Pilgrimage, migration, and the religious imagination, pp. 25-45, Routledge, London.

Mihelj, S., Leguina, A. \& Downey, J., 2019, 'Culture is digital: Cultural participation, diversity and the digital divide', New Media \& Society 21(7), 1465-1485. https:// doi.org/10.1177/1461444818822816

Mironova, K.V., 2019, 'The principle of open individuality as a basis for teenagers' creative interaction with lyric poems', Psychology in Russia: State of the Art 12(4), 135-147. https://doi.org/10.11621/pir.2019.0408

Mpondo, F, Ruiter, R.A.C. Schaafsma, D. Borne, B.V.D, \& Reddy, P.S, 2018 'Understanding the role played by parents, culture and the school curriculum in socializing young women on sexual health issues in rural South African communities', SAHARA-J: Journal of Social Aspects of HIV/AIDS 15(1), 42-49. https://doi.org/10.1080/17290376.2018.1455603

Mufti, M. \& Rahman, M.T., 2019, 'Fundamentalis dan Radikalis Islam di Tengah Kehidupan Sosial Indonesia', TEMALI: Jurnal Pembangunan Sosial 2(2), 204-218. https://doi.org/10.15575/jt.v2i2.4445

Ojala, M., Ladru, D.E. \& Gustafson, K., 2020, 'Parental reasoning on choosing the mobile preschool: Enabling sustainable development or adjusting to a neoliberal society?', Early Childhood Education Journal 49, 539-551. https://doi. org/10.1007/s10643-020-01083-z

Paley, J., 2016, Phenomenology as qualitative research: A critical analysis of meaning attribution, Taylor \& Francis, London.

Patrick, H.T., 2013, Dictionary of Islam, Hardpress Limited, Los Angeles, CA.

Rahman, M.T., 2010, 'Social justice in Western and Islamic thought: A comparative study of John Rawl's and Sayyid Qutb's theories of social justice', PhD thesis, University of Malaya Kuala Lumpur. 
Shadid, W. \& Koningsveld, S.V., 1996, 'Loyalty to a non-Muslim government', in political participation and identities of Muslims in non-Muslim states, pp. 84-115, Kok Pharos, Kampen.

Smith, D.R., Nixon, G. \& Pearce, J., 2018, 'Bad religion as false religion: An empirical study of UK religious education teachers' essentialist religious discourse', Religion 9(11), 361. https://doi.org/10.3390/rel9110361

Sohail, M.M., 2020, 'Belief in God's help during hepatitis C: A qualitative study on Muslim patients in Pakistan', Journal of Religion and Health 59(2), 928-945. https://doi.org/10.1007/s10943-018-0700-5

Swedberg, R., 2018, 'How to use Max Weber's ideal type in sociological analysis', Journal of Classical Sociology 18(3), 181-196. https://doi.org/10.1177/1468795X17743643

Thurbon, E., 2020, 'The future of financial activism in Taiwan? The utility of a mindsetcentred analysis of developmental states and their evolution', New Political Economy 25(3), 320-336. https://doi.org/10.1080/13563467.2018.1562436

Vanderlinden, J.-P., Baztan, J., Chouinard, O., Cordier, M., Cunha, C.D., Huctin, J.-M. et al., 2020, 'Meaning in the face of changing climate risks: Connecting agency, sensemaking and narratives of change through transdisciplinary research', Climate
Risk Management 29, 100224. https://doi.org/10.1016/j.crm.2020.100224
Verkuyten, M., 2018, 'Religious fundamentalism and radicalization among Muslim minority youth in Europe', European Psychologist 23(1). https://doi. minority youth in Europe',
org/10.1027/1016-9040/a000314

Vincini, S. \& Gallagher, S., 2020, 'Developmental phenomenology: Examples from social cognition', in Continental Philosophy Review, pp. 1-17, Springer, Berlin.

Vuori, J., Aher, K. \& Kylänen, M., 2020, 'The influence of Weber and Taylor on public sector organizations' communication', in The handbook of public sector communication, pp. 115-125, Routledge, London.

Weber, M., 1978, Economy and society: An outline of interpretive sociology, vol. 1 , University of California Press, Berkeley, CA.

Weber, M., 1993, The sociology of religion, Beacon Press, Boston, MA.

Weber, M., 2002, The protestant ethic and the 'spirit' of capitalism and other writings, Penguin, New York, NY.

Witt, M.A., 2019, 'De-globalization: Theories, predictions, and opportunities for international business research', Journal of International Business Studies 50(7) 1053-1077. https://doi.org/10.1057/s41267-019-00219-7 